Tohoku J. exp. Med., 1980, 130, 11-23

\title{
Immunosuppressive Factors in Pregnancy Serum: A Preliminary Report
}

\author{
Kunihiro Okamura, Masaki Kuramoto, Yoichi Hamazaki, \\ Katsuyuki Takahashi and Masakuni Suzuki \\ Department of Obstetrics and Gynecology, Tohoku University \\ School of Medicine, Sendai 980
}

\begin{abstract}
Okamura, K., Kuramoto, M., Hamazaki, Y., Takahashi, K., and Suzuki, M. Immunosuppressive Factors in Pregnancy Serum: A Preliminary Report. Tohoku J. exp. Med., 1980, 130 (1), 11-23 — A serum component with suppressive activity on human lymphocyte responses to phytohemagglutinin was examined in pregnancy serum. No correlation could be found between the elevated level of alpha-2-AP glycoprotein and the immunosuppressive activity. The active constituent was isolated by ultracentrifugation, salt fractionation, ion exchange chromatography and gel filtration. The immunosuppressive activity was found to be associated with alpha-globulin which consisted of neither lipoprotein nor alpha-2-AP glycoprotein. In terms of its antigenicity, the active fraction was found to be a mixture of 5 components. _ immunosuppression; alphaglobulin; pregnancy serum
\end{abstract}

It has long been a concern from the immunologic point of view that the histoincompatible embyro avoids immunologic attacks by the maternal immune system. A number of reports have indicated that the maternal immunologic capacity is depressed during pregnancy (Lichtenstein 1942; Andresen and Monroe 1962; Purtilo et al. 1972) and the immunologic suppression observed in the pregnant mother seems to be mainly due to the effect of the serum components rather than the depression of the lymphocyte function (Kasakura 1972; Leikin 1972; Hill et al. 1973). It is very interesting to see what kind of substances in the pregnancy sera are responsible for the immune suppression. Although many reports concerning the immunosuppressive factors in sera have been published, there have been few reports which concerned with the characterization of the immunosuppressive factors directly from the pregnancy sera, except for the report of Stimson and Blackstock (1976) stating that alpha-lipoprotein is responsible for the suppression induced by the late pregnant serum. Steroid hormones and human chorionic gonadotropin, which increase during pregnancy, have been reported to inhibit the blastformation of normal lymphocyte induced by PHA, but many times the concentration in pregnancy serum is needed to elicit the suppression. Schoulz (1974) reported that alpha-2-AP glycoprotein or pregnancy zone protein, which also increases during pregnancy and is now characterized as an acute phase

Received for publication, December 1, 1978. 
protein, might be one of the main immunosuppressive substances in pregnancy sera. In the present paper, however, we found no correlation between immunosuppressive activity and antigenic titers of alpha-2-AP glycoprotein in pregnancy serum. We identified an alpha-globulin fraction from pregnancy sera in which the main factors of immunosuppressive activity of pregnancy sera might be involved.

\section{Materials AND Methods}

Blood was obtained by venipuncture from about fifty pregnant women at 29-32 weeks of gestation. The blood donors had normal pregnancies. After centrifugation of the blood at 2,500 rpm for $10 \mathrm{~min}$, pregnancy serum was collected and stored at $-20^{\circ} \mathrm{C}$. $120 \mathrm{ml}$ of pregnancy serum as fresh as possible was used for identification of immunosuppressive factors.

Antigenic titers of alpha-2-AP glycoprotein. Precipitin lines were made with pregnancy sera against rabbit anti alpha-2-AP glycoprotein serum (Hoechst, Batch 2644) in $0.6 \%$ agar and $0.6 \%$ agarose gels. The antigenic titer was expressed as the reciprocals of the maximal dilution values of the sera to have made precipitin lines against the antisera.

Identification of lipoproteins. $20 \mathrm{ml}$ of pooled pregnancy serum was fractionated by ultracentrifugation using a Hitachi Rp-65-Ti rotor at $16^{\circ} \mathrm{C}$ (Hatch and Lees 1968). Four fractions were obtained. They were very low density lipoprotein (VLDL), low density lipoprotein (LDL), high density lipoprotein (HDL) and protein fractions. Each fraction was adjusted to $5 \mathrm{ml}$ with $0.01 \mathrm{M}$ phosphate buffer saline, followed by dialysation against a large amount of $0.15 \mathrm{M} \mathrm{NaCl}$ and then used for the assay of the lymphocyte responses. $20 \mu \mathrm{l}$ of each lipoprotein fraction was added to the cultures to examine their effects on lymphocyte blastogenesis.

Identification of immunosuppressive factors from pregnancy serum. As the protein rich fraction showed inhibitory activity on the lymphocyte responses, the pooled serum was adjusted to a density of $1.210 \mathrm{~g} / \mathrm{ml}$ by the addition of $\mathrm{NaBr}$ solution (density of 1.478 $\mathrm{g} / \mathrm{ml}: \mathrm{NaBr} 7.65 \mathrm{M}, \mathrm{NaCl} 0.195 \mathrm{M}, 0.001 \mathrm{M}$ EDTA) and centrifuged at 40,000 rpm for $40 \mathrm{hr}$ using the same rotor as described above. The upper portion, rich in floating lipoprotein, was removed with pasteur pipettes. The bottom fraction, rich in protein, was used as the immunosuppressor source and further purified.

Salt fractionation. The protein rich bottom portion was dialysed against $0.15 \mathrm{M} \mathrm{NaCl}$ to remove the excess $\mathrm{NaBr}$ and then precipitated with $40 \%$ to $70 \%$ saturated ammonium sulfate. After the mixture had been allowed to settle for $2 \mathrm{hr}$ at $4^{\circ} \mathrm{C}$, the precipitates were separated by centrifugation at $10,000 \mathrm{rpm}$ for $20 \mathrm{~min}$.

Ion exchange chromatography. The fractions precipitated with $40 \%$ saturated ammonium sulfate were dissolved in PBS and dialysed against $0.0175 \mathrm{M}$ sodium phosphate, followed by application to $2 \times 60 \mathrm{~cm}$ DEAE ion exchange columns (DE-22, Whatman) equilibrated with $0.0175 \mathrm{M}$ sodium phosphate buffer, $\mathrm{pH} 6.3$. The columns were eluted with four sodium phosphate solutions of increasing concentration and decreasing $\mathrm{pH}$ from $0.04 \mathrm{M}, \mathrm{pH} 5.9$ to $0.4 \mathrm{M}, \mathrm{pH} 4.4$.

Gel filtration. The active fraction separated with the DEAE cellulose column was further purified by gel filtration through a $2.6 \times 90 \mathrm{~cm}$ Sephadex G-200 column equilibrated with the same buffer. The proteins eluted from the DEAE cellulose column and Sephadex G-200 column were detected at $280 \mathrm{~nm}$ and the titers of the eluates measured by the Folin-Lowry method before addition to the lymphocyte cultures.

Analytical procedures. Electrophoresis of the samples was carried out on cellulose acetate membranes with $\mathrm{pH} 8.6$ barbiturate buffer at a constant current of $0.8 \mathrm{~mA} / \mathrm{cm}$ for $1 \mathrm{hr}$. The electrophoretogram was stained with panceau 3-R and the density of the staining measured by a densitometer, OZ-802 model (OZUMA, Japan).

Electrophoresis of the proteins was carried out on slab gels in a gradient polyacrylamide electrophoretic apparatus, GE-4 (Pharmacia, Sweden) using 0.01 M Tris-HCl buffer, $\mathrm{pH}$ 8.0 at $300 \mathrm{~V}$ for $4 \mathrm{hr}$. The gels were stained with amido black. 
Immunologic assay. The magnitude of the immunosuppressive effect of the pregnancy serum was determined by measuring the inhibitory activity on phytohemagglutinin (PHA)induced blastformation of normal human lymphocytes. Lymphocytes were obtained from normal healthy human donors by use of the gelatin sedimentation method. The lymphocytes were suspended so as to give $1.2 \times 10^{6}$ cells $/ \mathrm{ml}$ in RPMI 1640 medium supplemented with $10 \%$ fetal calf serum, $100 \mathrm{IU} / \mathrm{ml}$ penicillin and $100 \mu \mathrm{g} / \mathrm{ml}$ streptomycin. One tenth of a $\mathrm{ml}$ of the lymphocyte suspension was cultured in a microtiter plate (NUNC, Denmark) at $37^{\circ} \mathrm{C}$ in a humidified atmosphere of $5 \% \quad \mathrm{CO}_{2}$ and $95 \%$ air for $66 \mathrm{hr}$. Ten $\mu \mathrm{l}$ of $15 \mu \mathrm{g} / \mathrm{ml}$ PHA-P (Difco) and $10 \mu \mathrm{l}$ of the test sample with its protein concentration, adjusted as described above, were added at the time of culture initiation. All samples to be tested were dialysed against a large volume of PBS before addition to the culture. Eighteen $\mathrm{hr}$ before the completion of culture, $0.1 \mu \mathrm{Ci}{ }^{3} \mathrm{H}$-thymidine in $20 \mu \mathrm{l}$ of RPMI medium was added. The lymphocytes were harvested with a mini MASH extractor and the incorporation of ${ }^{\mathbf{3}} \mathrm{H}$-thymidine into lymphocyte DNA was counted by the Beckman Intertechnique liquid scintillation system. Culture was carried out in triplicate. The magnitude of inhibition was calculated according to the following equation:

$$
\% \text { Inhibition }=\left(1-\frac{c p m \text { with PHA and test sample }-c p m \text { without PHA }}{c \text { pm with PHA }- \text { cpm without PHA }}\right) \times 100
$$

\section{Results}

Pregnancy sera were obtained from fourteen women of eight months of gestation and their titers of alpha-2-AP glycoprotein were examined using anti alpha-2-AP glycoprotein serum in the same batch. The suppressive effect of each pregnancy serum was tested on the normal lymphocyte responses to PHA at $25 \%$ concentration in culture. Fig. 1 shows no correlations between the titers of alpha-2AP glycoprotein and immunosuppressive effect in pregnancy serum. Thus, it

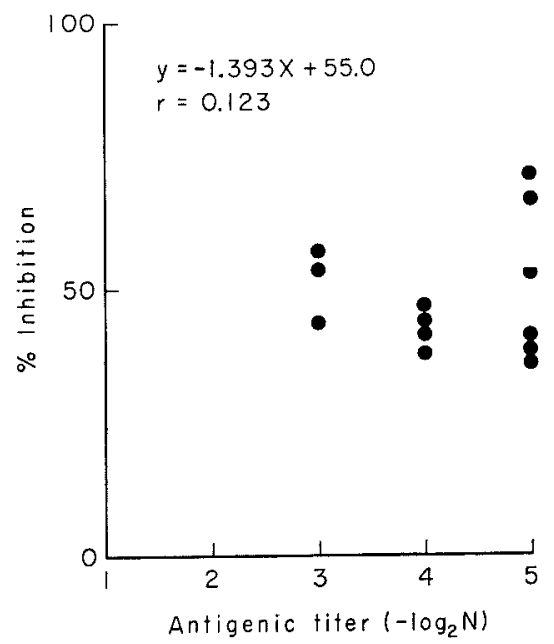

Fig. 1. No correlation between the antigenic titers of alpha-2-AP glycoprotein and the immunosuppressive effects of pregnancy sera. Immunosuppressive effect of pregnancy sera were evaluated at $25 \%$ per culture. $\mathrm{N}$, the reciprocal of maximun dilution values of pregnancy sera to have made precipitine lines against an antialpha-2-AP glycoprotein serum. 
cannot be said that alpha-2-AP glycoprotein is mainly responsible for the immunosuppressive activity of pregnancy serum.

The protein rich fraction from pregnancy sera was identified by its suppressive activity on lymphocyte transformation in vitro. However, each lipoprotein fraction separated by the floating method did not exhibit any immuno-suppressive effects (Table 1). As immunosuppressive factors could not be found in each lipoprotein fraction, large amount of pooled pregnancy serum was separated by ultracentrifugation into two main fractions, a lipoprotein rich and a protein rich fraction for the purpose of keeping out lipoprotein in further purification. Table 2 also shows that immunosuppressive activity was found only in the protein rich fraction. When the lipoprotein rich fraction was added to the culture at several different doses, the lymphocyte response to $\mathrm{PHA}$ was slightly enhanced in our system.

As the suppressive activity was always found in the protein rich fraction, it was further purified by precipitating with $40 \%$ saturated ammonium sulfate. After removal of the precipitate by centrifugation, ammonium sulfate was added to the

TABLE 1. Suppressive effect of the protein rich fraction against $P H A$ induced lymphocyte blastformation

\begin{tabular}{lccc}
\hline & $\begin{array}{c}\text { PHA } \\
(\mu \mathrm{g} / \mathrm{ml})\end{array}$ & $\begin{array}{c}{ }^{3} \text { H-Thymidine incorporation } \\
(\mathrm{cpm} \pm \mathrm{s.E})\end{array}$ & $\%$ Inhibition \\
\hline Control & 0 & $375 \pm 4$ & \\
& 15 & $19,580 \pm 1,879$ & \\
Pregnancy serum & 15 & $5,779 \pm 1,231$ & $\mathbf{7 2 . 3}$ \\
VLDL+chylomicron & 15 & $23,927 \pm 553$ & -22.6 \\
LDL & 15 & $19,656 \pm 1,158$ & -0.5 \\
HDL & 15 & $19,301 \pm 2,124$ & 1.5 \\
VHDL+protein & 15 & $578 \pm 3$ & 99.0 \\
\hline
\end{tabular}

VLDL, very low density lipoprotein; LDL, low density lipoprotein HDL, high density lipoprotein; VHDL, very high density lipoprotein.

TABLE 2. Comparison of suppressive effect on PHA induced lymphocyte blastformation between the protein rich fraction and the lipoprotein rich fraction

\begin{tabular}{|c|c|c|c|c|}
\hline & $\begin{array}{c}\text { PHA } \\
(\mu \mathrm{g} / \mathrm{ml})\end{array}$ & $\begin{array}{c}{ }^{3} \mathrm{H} \text {-Thymidine incorporation } \\
(\mathrm{cpm} \pm \mathrm{s} . \mathrm{E} .)\end{array}$ & $\%$ Inhibition & $\begin{array}{l}\text { Protein } \\
\text { recovery (\%) }\end{array}$ \\
\hline Control & $\begin{array}{r}0 \\
15\end{array}$ & $\begin{array}{rr}253 \pm & 61 \\
11,241 \pm & 903\end{array}$ & & \\
\hline Pregnancy serum & & & & \\
\hline $\begin{array}{c}20 \mathrm{mg} / \mathrm{ml} \\
\text { Lipoprotein rich }\end{array}$ & 15 & $4,593 \pm 1,420$ & 60.5 & \\
\hline fraction $(1.210)$ & & & & 9.2 \\
\hline $10 \mathrm{mg} / \mathrm{ml}$ & 15 & $19,141 \pm 2,168$ & -71.9 & \\
\hline $5 \mathrm{mg} / \mathrm{ml}$ & 15 & $24,842 \pm 916$ & -123.7 & \\
\hline $2.5 \mathrm{mg} / \mathrm{ml}$ & 15 & $23,000 \pm 1,415$ & -107.0 & \\
\hline Protein rich & & & & \\
\hline fraction $(1.210)$ & & & & 87.7 \\
\hline $25 \mathrm{mg} / \mathrm{ml}$ & 15 & $2,466 \pm \quad 380$ & 79.9 & \\
\hline $15 \mathrm{mg} / \mathrm{ml}$ & 15 & $4,609 \pm 1,184$ & 60.5 & \\
\hline $10 \mathrm{mg} / \mathrm{ml}$ & 15 & $8,586 \pm 233$ & 24.2 & \\
\hline
\end{tabular}


supernatant to make a $50 \%$ saturated solution. Precipitation was allowed to occur. The precipitate was referred to as the $40 \%-50 \%$ precipitate. The procedure was repeated for every $10 \%$ increase of ammonium sulfate and the precipitate $(40 \%$ precipitate, $40-50 \%, 50-60 \%, 60-70 \%)$ and the residue were tested for their lymphocyte suppressive activity after removal of the ammonium sulfate by extensive dialysis. As shown in Table 3, when the suppressive activity was evaluated with a $10 \mathrm{mg} / \mathrm{ml}$ protein solution from each fraction, the fraction precipitated with $40 \%$ saturation ammonium sulfate showed more than $80 \%$ suppression without affecting cell viability. The other fractions obtained from $40 \%$ to $50 \%, 50 \%$ to $60 \%, 60 \%$ to $70 \%$ saturated ammonium sulfate precipitation and the components not precipitated by $70 \%$ saturation of ammonium sulfate did not affect lymphocyte proliferation.

TABLE 3. Comparison of the suppressive effect of the proteins precipitated with different concentrations of ammonium sulfate

\begin{tabular}{|c|c|c|c|c|}
\hline & $\begin{array}{c}\text { PHA } \\
(\mu \mathrm{g} / \mathrm{ml})\end{array}$ & $\begin{array}{c}{ }^{3} \text { H-Thymidine incorporation } \\
(\mathrm{cpm} \pm \text { s.E. })\end{array}$ & $\%$ Inhibition & $\begin{array}{c}\text { Protein } \\
\text { recovery }(\%)\end{array}$ \\
\hline Control & $\begin{array}{r}0 \\
15\end{array}$ & $\begin{array}{r}407 \pm 297 \\
27,180 \pm 1,621\end{array}$ & & \\
\hline $\begin{array}{r}\left(\mathrm{NH}_{4}\right)_{2} \mathrm{SO}_{4} \\
0.4 \mathrm{ppt}\end{array}$ & & & & 50.0 \\
\hline $10 \mathrm{mg} / \mathrm{ml}$ & 15 & $4,802 \pm \quad 764$ & 83.6 & \\
\hline $\begin{array}{l}5 \mathrm{mg} / \mathrm{ml} \\
0.4-0.5\end{array}$ & 15 & $17,214 \pm 2,823$ & 27.2 & 2.1 \\
\hline $10 \mathrm{mg} / \mathrm{ml}$ & 15 & N.D. & & \\
\hline $5 \mathrm{mg} / \mathrm{ml}$ & 15 & $29,302 \pm \quad 596$ & -7.9 & \\
\hline $0.5-0.6$ & & & & 17. 7 \\
\hline $10 \mathrm{mg} / \mathrm{ml}$ & 15 & $31,383 \pm 1,431$ & -15.7 & \\
\hline $5 \mathrm{mg} / \mathrm{ml}$ & 15 & $34,466 \pm 1,143$ & -27.9 & \\
\hline $0.6-0.7$ & & & & 9.8 \\
\hline $10 \mathrm{mg} / \mathrm{ml}$ & 15 & $30,469 \pm 1,210$ & -12.3 & \\
\hline $5 \mathrm{mg} / \mathrm{ml}$ & 15 & $38,059 \pm 1,801$ & -40.6 & \\
\hline $0.7 \mathrm{sup}$ & & & & 3.1 \\
\hline $10 \mathrm{mg} / \mathrm{ml}$ & 15 & $30,121 \pm \quad 924$ & -11.0 & \\
\hline $5 \mathrm{mg} / \mathrm{ml}$ & 15 & $29,593 \pm 1,320$ & -9.0 & \\
\hline
\end{tabular}

The fraction precipitated with $40 \%$ saturated ammonium sulfate was then chromatographed on a DEAE cellulose column. Five peaks, A, B, C, D and E, were obtained after elution (Fig. 2). Each fraction but $\mathrm{E}$ was tested for its inhibitory activity on the lymphocyte responses induced with PHA. The four major fractions were electrophoresed on cellulose acetate membranes. Fraction A was located in the gamma-globulin region and Fraction $B$ in the beta-globulin region A large amount of albumin and relatively small amount of alpha-globulin were detected as the main components in Fraction C. Fraction D was composed of alpha-globulin and a small amount of albumin (Fig. 3). When each fraction was added to the lymphocyte culture so as to make a final concentration of $1 \mathrm{mg}$ or $2.5 \mathrm{mg}$ protein $/ \mathrm{ml}$, only fractions $\mathrm{C}$ and $\mathrm{D}$ inhibited the lymphocyte responses to PHA (Table 4). Considering that suppressive activity was recovered from Fraction 


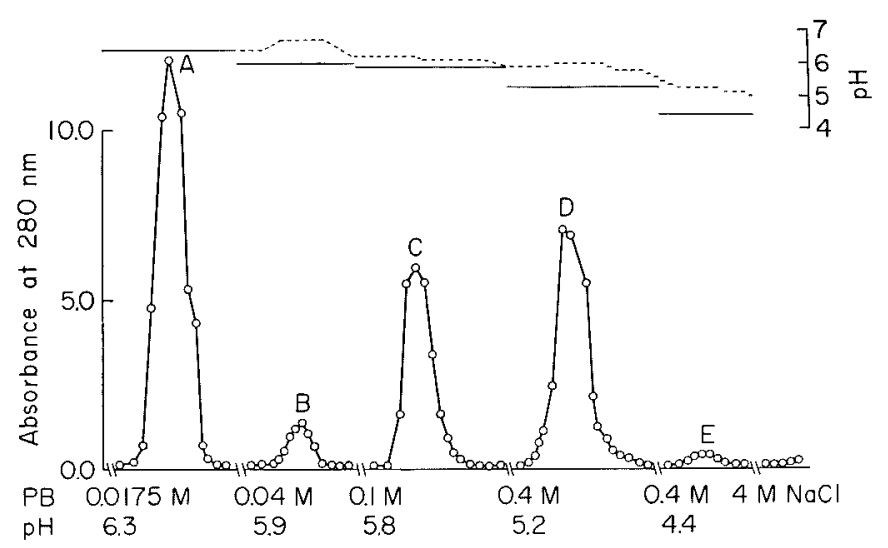

Fig. 2. DEAE-cellulose column chromatograph of the $40 \%$ saturated ammonium sulfate precipitate. The precipitate with $40 \%$ saturated ammonium sulfate was applied to $2 \times 60 \mathrm{~cm}$ DEAE ion exchange column equilibrated with $0.0175 \mathrm{M}$ sodium phosphate buffer. The column was eluted with four sodium phosphate solutions.
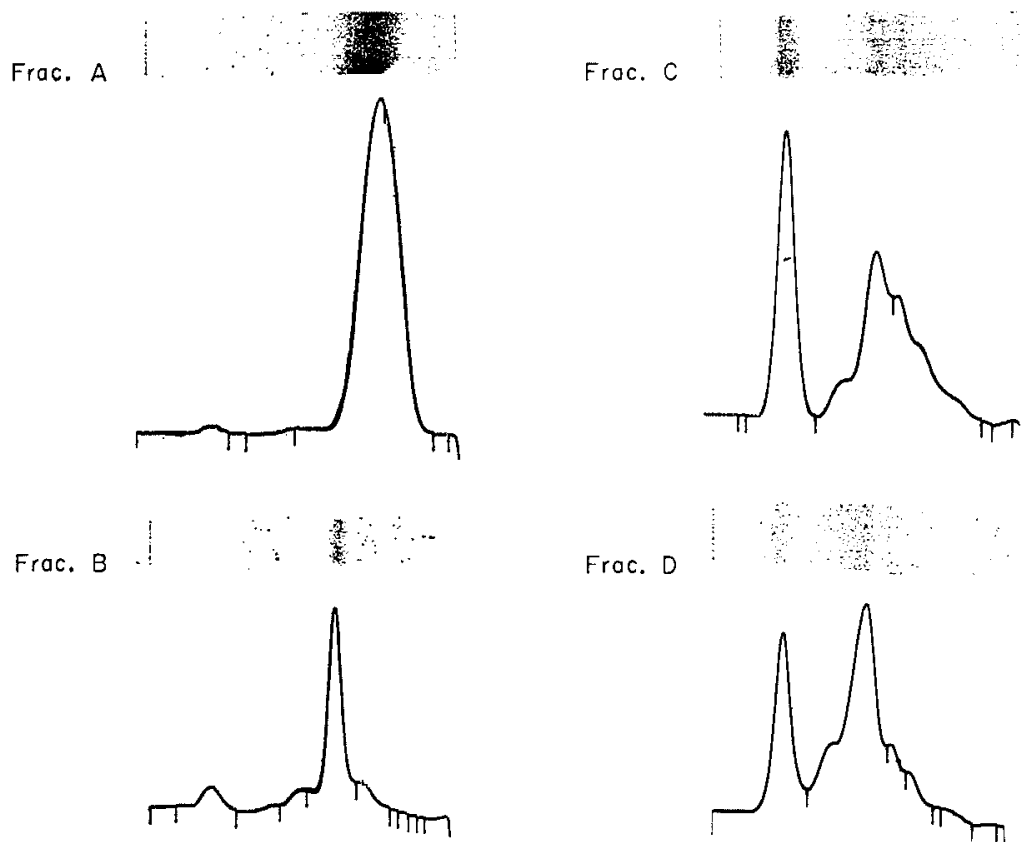

Frac. D

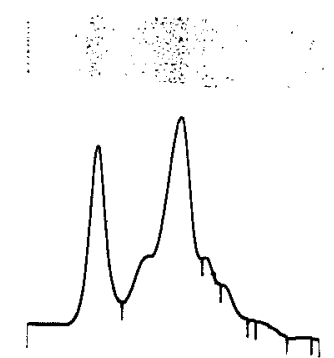

Fig. 3. Electrophoretic pattern of $40 \%$ ammonium sulfate precipitates by DEAE cellulose chromatography.

$\mathrm{D}$ at high efficiency, it is unlikely that a main suppressor component would be recovered from Fraction E. The magnitude of the suppressive activity of Fraction $\mathrm{D}$ was $80 \%$ at $2.5 \mathrm{mg}$ protein $/ \mathrm{ml}$ and $50 \%$ at $1.0 \mathrm{mg}$ protein $/ \mathrm{ml}$. The suppressive activity of Fraction $\mathrm{C}$ was evident only at a dose of $2.5 \mathrm{mg}$ protein $/ \mathrm{ml}$. 
TABLE 4. Suppressive effect of fractions by DEAE cellulose chromatography from the precipitates of $40 \%$ saturated ammonium sulfate on $P H A$ induced lymphocyte blastformation

\begin{tabular}{|c|c|c|c|c|}
\hline & $\underset{(\mu \mathrm{g} / \mathrm{ml})}{\mathbf{P H A}}$ & $\begin{array}{c}{ }^{3} \mathrm{H} \text {-Thymidine incorporation } \\
\text { (cpm } \pm \text { s.E. })\end{array}$ & $\%$ Inhibition & $\begin{array}{c}\text { Protein } \\
\text { recovery }(\%)\end{array}$ \\
\hline Control & 0 & $313 \pm$ & & \\
\hline Fraction A & 15 & $24,415 \pm \quad 494$ & & \\
\hline $2.5 \mathrm{mg} / \mathrm{ml}$ & 15 & $20.415 \pm 515$ & 19.2 & 22.5 \\
\hline $1.0 \mathrm{mg} / \mathrm{ml}$ & 15 & $19,526 \pm 1,705$ & 20.3 & \\
\hline Fraction $\bar{B}$ & & & & 2.1 \\
\hline $2.5 \mathrm{mg} / \mathrm{ml}$ & 15 & $21,295 \pm \quad 441$ & 12.9 & \\
\hline $1.0 \mathrm{mg} / \mathrm{ml}$ & 15 & $25,370 \pm 1,186$ & -3.9 & \\
\hline Fraction $\mathrm{C}$ & & & & 6.9 \\
\hline $2.5 \mathrm{mg} / \mathrm{ml}$ & 15 & $11,826 \pm 2,440$ & 52.5 & \\
\hline $1.0 \mathrm{mg} / \mathrm{ml}$ & 15 & $22,370 \pm 1,096$ & 8.5 & \\
\hline Fraction D & & & & 8.9 \\
\hline $2.5 \mathrm{mg} / \mathrm{ml}$ & 15 & $4,982 \pm \quad 167$ & 80.6 & \\
\hline $1.0 \mathrm{mg} / \mathrm{ml}$ & 15 & $12,248 \pm 1,939$ & 50.5 & \\
\hline Fraction $\mathbf{E}$ & & N.D. & & 0.5 \\
\hline
\end{tabular}

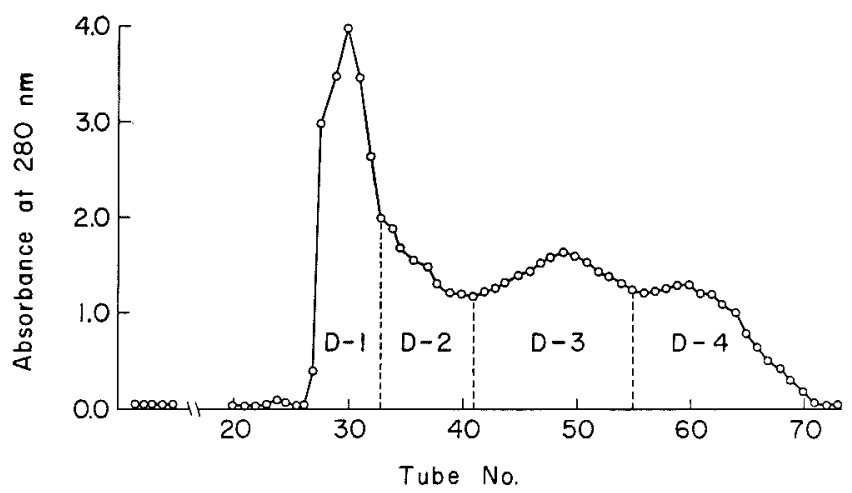

Fig. 4. Sephadex G-200 column chromatography of fraction D. Five ml was collected in each tube. Columns of $2.6 \times 90 \mathrm{~cm}, 0.01 \mathrm{M}$ phosphate buffer for elution.

Considering that the alpha-globulin rich fractions were more suppressive on the lymphocyte responses, alpha-globulins, not lipoproteins, are most likely to be the factor(s) responsible for immune suppression in pregnancy. Fraction D was separated by Sephadex G-200 column chromatography and four fractions, D-1, D-2, D-3 and D-4 were obtained (Fig. 4). The immunosuppressive activity was found mainly in Fraction D-4 which had a molecular weight smaller than that of albumin. In light of these results, the immunosuppressive factors in pooled pregnancy serum are most likely involved in Fraction D-4. Immunoelectrophoresis of D-4 on agar gel showed five components including albumin, alpha-1 antitrypsin, alpha-1acid glycoprotein, ceruloplasmin and transferrin (Table 5, Fig. 5). Fraction D, rich in alpha-globulin, was isolated from another unit of pooled pregnancy serum and tested for immunosuppressive effect at various doses. As shown in Fig. 6, the 
TABLE 5. Suppressive effect of fractions isolated further by Sephadex G-200 column on lymphocyte blastformation induced with $P H A$

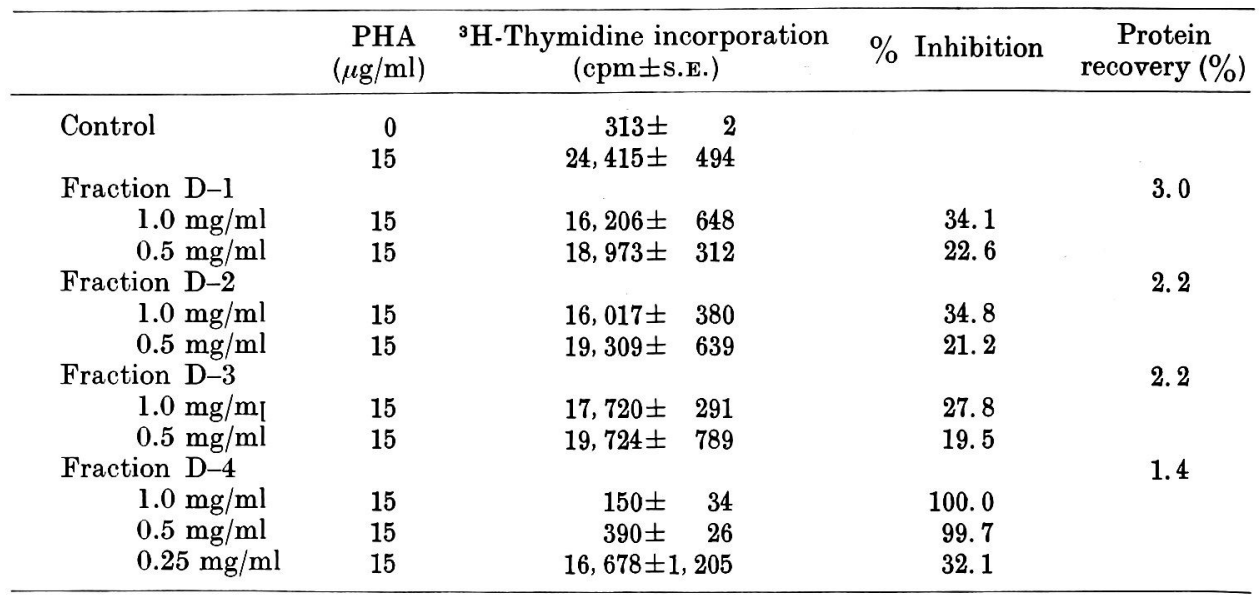

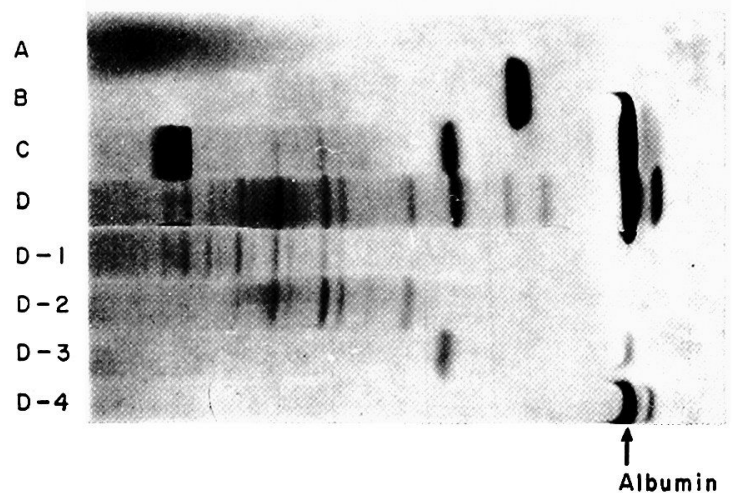

Fig. 5. Electrophoretic pattern of each fraction carried out on slab gels in a gradient polyacrylamide. Each fraction was applied in $10 \mu \mathrm{l}$.

blastformation of normal lymphocytes was completely inhibited by the addition of Fraction D at $2.5 \mathrm{mg} / \mathrm{ml}$. However, at the dose of $0.5 \mathrm{mg}$ protein $/ \mathrm{ml}$, we found no inhibition of the blastformation of normal lymphocyte. The crude alpha-globulin fraction, Fraction D, was inhibitory even at increased dose of PHA concentration and was relatively heat-stable (data not shown). Fig. 7 shows the change of immunosuppressive effect of fraction $D$ at various times of addition to the culture. Suppressive effect was most remarkable when added at the initiation of the culture system and slightly diminished $48 \mathrm{hr}$ thereafter.

\section{Discussion}

Lichtenstein (1942) observed the depression of PPD skin test during the third trimester of pregnancy. Depression of immune reactivity during late pregnancy has also been reported by Kasakura (1972), Leikin (1972), Walker et al. (1972), 


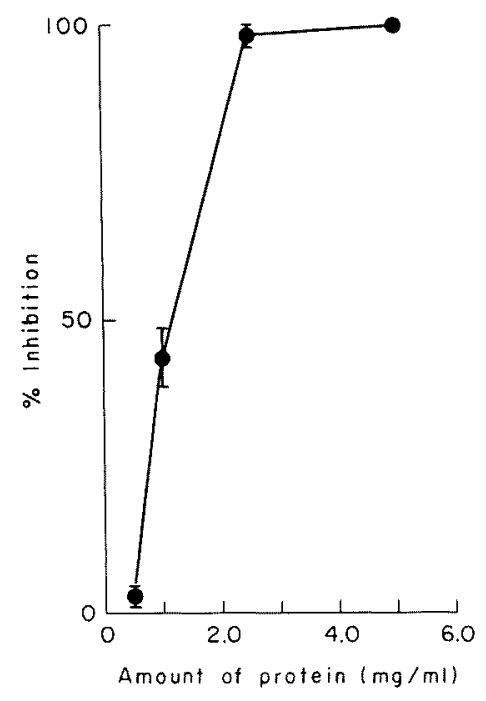

Fig. 6

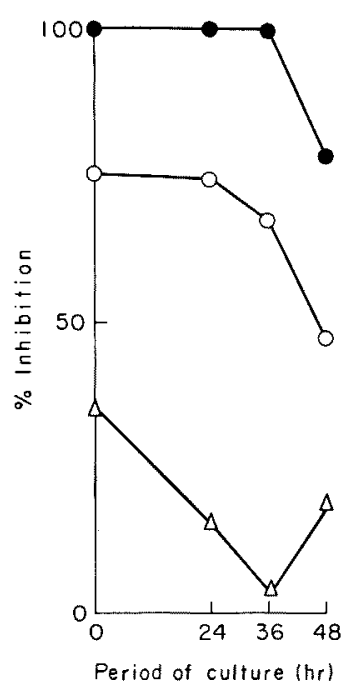

Fig. 7

Fig. 6. Suppressive effect of fraction D on the PHA-stimulated lymphocytes. The abscissa indicates the amount of protein per ml.

Fig. 7. The effect of fraction D on the PHA-stimulated lymphocytes when added at various periods of culture.

$\bullet-\bullet, 2.5 \mathrm{mg}$ protein $/ \mathrm{ml} ; 0-0,1.0 \mathrm{mg}$ protein $/ \mathrm{ml} ; \Delta-\Delta, 0.5 \mathrm{mg}$ protein $/ \mathrm{ml}$

Purtilo et al. (1972) and Saito et al. (1975). These authors indicated that a serum factor is responsible for the suppression of the immune capacity of pregnant mothers.

Human chorionic gonadotropin (HCG) and steroid hormones have been reported to suppress lymphocyte blastformation caused by PHA. However, these hormones could not be considered as the most responsible factors for the immunosuppression of pregnancy serum because quite large amounts of each hormone were necessary to induce the immunosuppression (Kaye and Jones 1971; Wyle and Kent 1977).

Schoulz et al. (1974) isolated alpha-2-AP glycoprotein, pregnancy zone protein, from retroplacental blood. They reported that purified alpha-2-AP glycoprotein exerted suppressive activity on cell-mediated immune responses. They also observed that the pregnancy serum of over $100 \mathrm{mg} / 100 \mathrm{ml}$ in its concentration was more immunosuppressive than that of under $100 \mathrm{mg} / 100 \mathrm{ml}$. They thought that this protein may be the most important immunosuppressive factor in pregnancy serum. In our system, however, we could not find any correlation between the elevated serum level of alpha-2-AP glycoprotein and the suppressive activity in late pregnancy serum. We demonstrated the presence of this glycoprotein not in the most suppressive fraction, D-4, but D-2. From our results, we do not believe that alpha-2-AP glycoprotein is the main component of immunosuppressive factors. 
Immunosuppressive activity of serum has been shown in various deseases, for example, cancer, liver cirrhosis, rheumatoid arthritis and sarcoidosis. It is interesting and important to examine whether the immunosuppressive factors in the sera of these diseases may differ from those in pregnancy.

Occhino et al. (1973) isolated immunoregulatory alpha-globulin, IRA, from the Cohn IV-1 fraction of normal human sera. They also found the active moiety of the alpha-globulin to be a peptide which was easily isolated from the carrier protein at low $\mathrm{pH}$ and high salt concentration. As the isolating procedures of our system are partly similar to those of IRA, such an investigation should be carried out with our preparation. Elevated serum levels of IRA have also been repeatedly documented in association with the suppressed state of immune reactivity in tumor bearing hosts (Glasgow et al. 1974).

Alpha-fetoprotein, found in sera of fetuses and patients with cancer, is also known to be immunosuppressive (Murgita and Thomasi 1975; Yachnin 1976). We also observed that alpha-fetoprotein was suppressive lymphocyte blastformation at the dose of $1 \mathrm{mg} / \mathrm{ml}$. Although we cannot exclude the possibility of involvement of alpha-fetoprotein in our preparation, we do not believe that this protein is responsible for immunosuppression in light of the fact that the maximum pregnancy serum level of alpha-fetoprotein was reported to be about $250 \mathrm{ng} / \mathrm{ml}$ at $35-38$ weeks gestation (Ishiguro and Nishimura 1973).

Urushizaki et al. (1971) found an immunosuppressive alpha-2 macroglobulin which could be detected only in cancer serum. Alpha-2 macroglobulin could be found in fraction $\mathrm{C}$ in large amounts in our preparation, which is not responsible for the immunosuppressive activity on pregnancy serum.

Alpha-1-acid glycoprotein, seromucoid, is one of the acute phase proteins and has been shown to be elevated during pregnancy (Adams and Wacher 1968). Jenkins et al. (1973) reported that the mixed leukocyte reaction of cells from women and their husbands was considerably less active when maternal seromucoid was present in the culture than when it is absent. Chiu et al. (1977) showed that alpha-1acid glycoprotein, isolated from human ascites, has a capacity to inhibit both lymphocyte blastformation induced by PHA and unidirectional mixed lymphocyte culture reaction. Onda (1977) reported that alpha-1-acid glycoprotein had inhibitory activity on the mitosis of regenerating rat liver cells. In this study, a considerable amount of alpha-1-acid glycoprotein was contained in our suppressive fraction. It is most likely, therefore, that elevated serum levels of alpha-1-acid glycoprotein during the third trimester are closely related to the immune suppression. The serum level of alpha-1-acid glycoprotein is known to increase in inflammation, cancer and rheumatoid arthritis as well as in pregnancy and alpha-1-acid glycoprotein has been reported to be produced in liver cells. Recently, Gahmberg and Andersson (1978) observed that alpha-1-acid glycoprotein exists on the cell surfaces of $\mathrm{T}$ lymphocyte, $\mathrm{B}$ lymphocyte, granulocyte and monocyte and that it increases in amount specially at their blastformation. Therefore, the elevation of serum level of alpha-1-acid glycoprotein may be due to its systhesis not only 
in liver cells, but in lymphocytic cells, as well. Although the biological role of alpha-1-acid glycoprotein has not yet been well clarified, it seems likely that it protect cells from antibody attack through its structual similarity to immunoglobulins. Alpha-1-acid glycoprotein may protect the fetus by suppressing lymphocyte reactivity and inhibiting humoral antibody attack when it is attached to the surface of trophoblast membranes.

Curtis and Edginton (1976) reported that low density lipoproteins (LDL) has regulatory activity on the lymphocyte responses. Chisari (1977) showed that very low density lipoprotein also has a capacity to suppress lymphocyte blastogenesis. Stimson and Blackstock (1976) reported that high density lipoprotein (HDL) or alpha-lipoprotein, which was isolated from pregnancy serum by gel filtration, had inhibitory effects in BCG-induced leukocyte migration test. In the present study, however, we could not detect immunosuppressive activity in either LDL or HDL, isolated by the floating method. Although the discrepancy between the present results and others' is not yet well understood, it must be considered that lipoproteins are very changeable in nature and can induce various effects in an in vitro system. We would like to stress that, above all else, it is necessary to keep lipoproteins out of the serum at the early stage of procedures.

After keeping out lipoproteins at first by the floating method, we isolated an alpha-globulin fraction by ammonium sulfate precipitation, ion exchange chromatography and gel filtration, in turn. The responsible immunosuppressive factors were considered to be involved in the alpha-globulin fraction, which contains neither lipoprotein nor alpha-2-AP glycoprotein.

The alpha-globulin found in this study consisted of five components including albumin, alpha-1 antitrypsin, alpha-1-acid glycoprotein, ceruloplasmin and transferrin. Whether immune suppression during late pregnancy is induced by all of the above five components or some of them is of great interest. It will be necessary for us to examine the immunosuppressive activity of each protein.

Olding and Oldstone (1976) showed that $\mathrm{T}$ lymphocytes from the newborn suppress their own mother's lymphocyte response to PHA. A subset of T lymphocytes produces an immunosuppressive factor. It is of interest whether or not this kind of fetal lymphocyte would act in maternal blood and protect the fetus from maternal immunologic attacks. Whether or not $\mathrm{T}$ lymphocyte product from the fetus is involved in our preparation should be examined.

Other components in fraction D-4, albumin, alpha-1 antitrypsin, ceruloplasmin and transferrin have not been reported to have immunosuppressive capacity, but we cannot at this time, deny the possibility that active moieties may be bound to these proteins.

\section{References}

1) Adams, J.B. \& Wacher, A. (1968) Specific changes in the glycoprotein components of seromucoid in pregnancy. Clin. chim. Acta, 21, 155-157.

2) Andresen, R.H. \& Monroe, C.W. (1962) Experimental study of the behavior of adult human skin during pregnancy. Amer. J. Obstet. Gynec., 84, 1096-1103. 
3) Chisari, F.V. (1977) Immunoregulatory properties of human plasma in very low density lipoproteins. J. Immunol., 119, 2129-2135.

4) Chiu, K.M., Mortensen, A.P., Osmand, A.P. \& Gewurz, H. (1977) Interactions of alpha-1-acid glycoprotein with the immune system. Immunology, 32, 997-1005.

5) Curtis, L.K. \& Edginton, T.S. (1976) Regulatory serum liporoteins; regulation of lymphocyte stimulation by a species of low density lipoprotein. $J$. Immunol., 116, $1452-1458$.

6) Gahmberg, C.G. \& Andersson, L.C. (1978) Leukocyte surface origin of human alpha-1acid glycoprotein (orosomucoid). J. exp. Med., 148, 507-521.

7) Glasgow, A.H., Nimberg, R.B., Menzoian, J.O., Saporoschetz, L., Cooperband, S.R., Schmid, K. \& Mannick, J.A. (1974) Association of anergy with an immunosuppressive peptide fraction in the serum of patients with cancer. New Engl. J. Med., 291, 1236-1267.

8) Hatch, F. \& Lees, R.S. (1968) Practical methods for plasma lipoprotein analysis. In: Advances in Lipid Research. vol. 6, Academic Press, New York, p. 1.

9) Hill, C.A., Finn, R. \& Denye, V. (1973) Depression of cellular immunity in pregnancy due to a serum factor. Brit. med. J., 3, 513-514.

10) Ishiguro, T. \& Nishimura, T. (1973) Radioimmunoassay of maternal serum alphafetoprotein associated with pregnancy. Amer. J. Obstet. Gynec., 116, 27-33.

11) Jenkins, D.M., Good, W. \& Good, S.M. (1973) Serum seromucoid and the maternopaternal mixed leukocyte reaction following previous severe pre-eclampsia. J. Obstet. Gynaec. Brit. Cwtth, 80, 19-20.

12) Kasakura, S. (1972) The inhibitory effect of pregnant plasmas on the reactivity of mixed leucocyte culture. In: Proceedings of the Sixth Annual Leucocyte Culture Conference, Academic Press, New York, p. 711.

13) Kaye, M.D. \& Jones, W.R. (1971) Effect of human chorionic gonadotropin on in vitro lymphocyte transformation. Amer. J. Obstet. Gynec., 109, 1029-1031.

14) Leikin. S. (1972) The immunosuppressive effect of maternal plasma. In: Proceedings of the Sixth Annual Leucocyte Culture Conference, Academic Press, New York, p. 725.

15) Lichtenstein, M.R. (1942) Tuberculin reaction in tuberculosis during pregnancy. Amer. Rev. Tuberc. pulmonary Dis., 46, 89-92.

16) Murgita, R. \& Thomasi, T.B., Jr. (1975) Suppression of the immune response by alphafetoprotein. J. exp. Med., 141. 269-286.

17) Occhino, J.C., Glasgow, A.H., Cooperband, S.R., Mannick, J.A. \& Schmid, K. (1973) Isolation of an immunosuppressive peptide fraction from human plasma. $J$. Immunol., 110, 685-694.

18) Olding, L.B. \& Oldstone, M.B. (1976) Thymus-derived peripheral lymphocyte from human newborns inhibit division of their mother's lymphocyte. J. Immunol., 116, $682-686$.

19) Onda, H. (1977) Alpha-1-acid glycoprotein and alpha-1 antitrypsin as mitotic inhibitors in regenerating rat liver. Gann, 68, 30I-306.

20) Purtilo, D.T., Hallgren, H.M. \& Yunis, E.J. (1972) Depressed maternal lymphocyte response to phytohemagglutinin in human pregnancy. Lancet, 1, 769-770.

21) Saito, T., Takada, M. \& Ishida, N. (1975) Inhibition of PHA-induced lymphocyte stimulation by factors in maternal serum during late pregnancy. Tohoku J. exp. Med., 116, 77-80.

22) Schoulz, B. von (1974) A quantitative study of the pregnancy zone protein in the sera of pregnant and puerperal women. Amer. J. Obstet. Gynec., 119, 792-797.

23) Schoulz, B. von, Stigbrand, T. \& Tarnvik, A. (1974) Inhibition of PHA-induced lymphocyte stimulation by the pregnancy zone protein. FEBS Letter, 38, 23-24.

24) Stimson W.H. \& Blackstock J.C. (1976) Identification of an immunosuppressive factor in pregnancy serum. Obstet. Gynec. 48, 305-311.

25) Urushizaki, I., Ishitani, K. Nagai, T., Gocho, Y. \& Koyama, R. (1977) Immunosuppressive factors in serum of patients with gastric carcinoma. Gann, 68, 413-421. 
26) Walker, J.S., Freeman, C.B. \& Harris, R. (1972) Lymphocyte reactivity in pregnancy. Brit. med. J., 3, 469.

27) Wyle, F.A. \& Kent, J.R. (1977) Immunosuppression by sex steroid hormones. Clin. exp. Immunol., 27, 407-415.

28) Yachnin, S. (1976) Demonstration of the inhibitory effect of human alpha-fetoprotein on in vitro transformation of human lymphocytes. Proc. nat. Acad. Sci. USA, 73, 28572861 . 